SOPHIA

Crossing Borders, Shifting Boundaries - The Aura of the Image

Issue 1- 2016

(c)scopio Editions

ISSN 2183-9468 [online version]

http://sophiajournal.net/

\title{
From the ruins of Beirut by the reflexions on some Ray-Bans to the visionary experiences in the stereoscopic photographs by Francisco Afonso Chaves (1857-1926)
}

Vítor dos Reis

\begin{abstract}
From a photograph (2007 World Press Photo Award) taken in the Summer of 2006 by the photojournalist Spencer Platt (1970- ) in a ruined Beirut, after Israeli bombings, the text tries, through the concept(s) of visual representation, to discuss the disintegration of the boundaries between the visible and the invisible in photographic images and to demonstrate how this disintegration leads the viewer to operate the construction of the visual. In this process he builds himself up as something more than the visual subject: a seer subject capable of visionary perceptive experiences. Divided into three parts: presence /apparition, vision/clairvoyance and image/reflection, the present essay goes back to the unknown stereoscopic photographic work of the Portuguese naturalist Francisco Afonso Chaves (1857-1926) and, in particular, to his experience regarding the fusion of different images, with the intention of comprehending how, in Portugal, these constitute one of the pioneer cases of visual extension through photography.
\end{abstract}

\footnotetext{
Vitor dos Reis Born in the city of Luanda (1965) he has graduated in Painting (ESBAL - Higher School of Fine Arts, 1990) and obtained a PHD in Fine Arts/ Theory of Image (University of Lisbon, 2007). President of the Higher School of Fine Arts of the University of Lisbon. He has published the book O Olho Prisioneiro e o Desafio do Céu: A Primeira Demonstração Perspéctica de Filippo Brunelleschi como Invenção e Paradigma da Perspectiva Central (Lisboa, FBAUL, 2002). Most recent individual exhibition: Sete Visões da Melancolia e Cinco do Acaso (Caparica, Convento dos Capuchos, 2002). Speaker at the international conference ECREA 2014 (European Communication and Research Association), in Lisbon (November, 2014) and at the international congress SCMS 2015 (Society for Cinema \& Media Studies), in Montreal (March 2015). Member of the scientific and organizing committees of the international conference Stereo \& Immersive Media 2015 and 2016 (Lisbon). Curator of the exhibition A República e a Modernidade (Ponta Delgada, Museu Carlos Machado, 2010). Co-author of the current secondary school drawing programs. He is currently developing a postdoctoral research on the relationships between art and science in the stereoscopic photographic work of the naturalist Francisco Afonso Chaves (1857-1926), that will culminate in 2016-2017 with three national exhibitions (MNAC-MC, Lisboa; MUHNAC, Lisboa; Museu Carlos Machado, Ponta Delgada). Research and publication areas: Theory of Image; Visual Culture, Art, Science and Technology; Spatial Representation.
} 


\section{From the ruins of Beirut by the reflexions on some Ray-Bans to the visionary experiences in the stereoscopic photographs by Francisco Afonso Chaves (1857-1926)}

Vítor dos Reis

\section{Prologue: five young people, four Ray-Ban and a red convertible}

In the Summer of 2006, in response to the kidnapping of Israeli soldiers by the Hezbollah, Israel bombarded, for almost five weeks, cities and villages in the Southern Lebanon - in particular, Beirut. On the $14^{\text {th }}$ August a ceasefire was announced. On that day, thousands of Lebanese began to return to their homes. In the capital, five young people, four girls and a boy, while riding in a red convertible, spotlessly cleaned and shiny, are photographed by Spencer Platt (1970-), in the midst of dust, smoke and a pile of rubble, on a street in the Haret Hreik neighbourhood [Fig. 1]. They wear modern clothes and, four of them, have mirrored sunglasses. The boy drives the vehicle slowly - or so we suppose. Three girls look away from the field of vision, in the photographer's direction, looking at the ruins that we cannot see. The other is focused on a mobile phone - maybe photographing this side of the world. One, out of these three who look in our direction, covers her nose with a white handkerchief.

This photograph, by the American Spencer Platt, awarded with the 2007 World Press Photo award, which became controversial right after its publication, is profoundly theatrical and paradoxical. It shows, in a first plane, so narrow and cluttered that it seems almost claustrophobic, these five young people clearly differentiated from everything that surrounds them: young, beautiful, elegant (maybe rich) and full of life, surrounded by destruction, ugliness and death, facing the antinomies of a country and a society, Lebanon. Most of all, it reveals the contradictions in human nature and in the categories through which we think and evaluate an individual and society: decadence and ugliness. However, while deeply aware of the devastation around them, these five young people do not seem to belong to it; seated in their sort of modern barge they are just passing by: navigating through the ruins they will quickly disappear and only a cloud of dust remains from them?

Glamour erupts in the middle of the war making this picture looking almost unreal. The five young Lebanese seem to be on a stage: in front of us, looking at our direction, at where the photojournalist is, at where we are, through him and his camera, where the ruins of Beirut are reflected on some Ray-Ban brown mirror gold lenses of the two girls who are closest: one brunette dressed in black and the other one, blonde, dressed in white. Through these images reflected on the oldest visual machines in history - mirrors - we see more: we see, as in the mirror hanging on the back wall of the

1 In the background, arranged in a transverse line, five men and a woman separate the red convertible from the backdrop: two of these people ignore the young people with Ray-Bans, two of them look at the others and one seems to look straight at the photographer - and at us - while walking. 


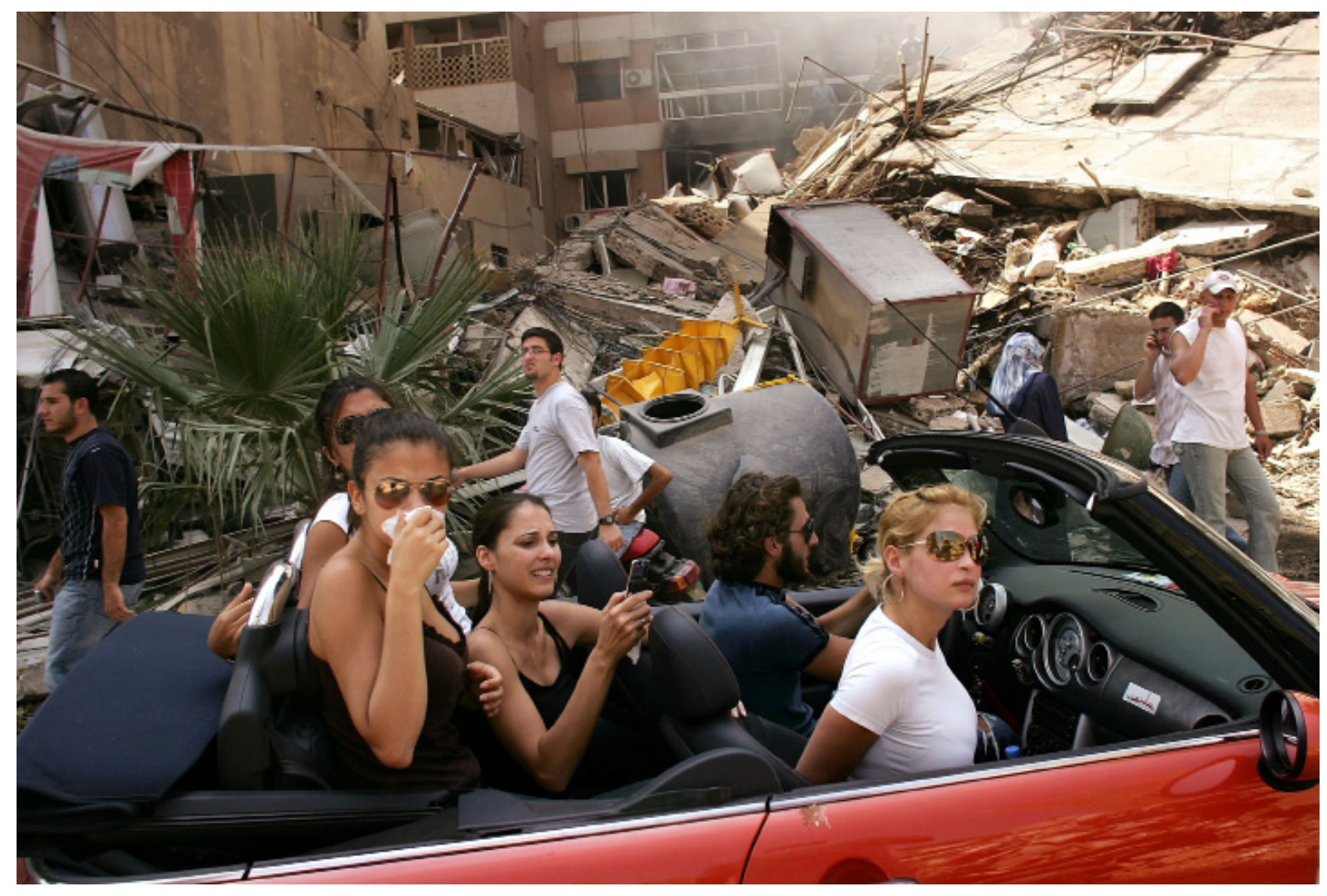

[Fig. 1]

SPENCER PLATT (1970-)

Beirut 2006

2007 World Press Photo award 
room in Arnolfini Portrait by Jan van Eyck (c.1390-1441) what we otherwise could not see because it is located behind the camera, behind Spencer Platt, Van Eyck and behind us. We become present through these miniaturized reflections of the world: we are there. Thereby, not only do we acquire the status of privileged observers, but we become eyewitnesses of what, otherwise, we would never see. Finally [Fig. 2], we acquire the sense of presence in a world outside our reality.

Thus, through the mirrored Ray-Ban we bypass the biological limits of human vision, we broaden the cognitive ability to build the visible and so expand our awareness of it. Through the mirrored Ray-Ban we escape from the claustrophobia of photography and of the visible: entangled in a web of crossed glances, visions and reflections, we finally have a glimpse of Beirut's debris in that Summer of 2006. And, as stated by Van Eyck, in the sentence written below the mirror painted on the back wall of the room, we can say we were here ${ }^{2}$. In this place, in this space, wide and virtual. A space beyond the surface's image, but also ahead of it. A space that, going beyond the visible, is, therefore, one of the most remarkable proofs of the complex construction of the visual to which art dedicates itself. Ambiguous, fascinating, unreal.

\section{Presence/Apparition}

Spencer Platt's photograph confronts us with some fundamental questions about images and visuality: what are the differences between the visible and the visual; starting from a representation, how do we build our sense of presence in a visual context where we have never been; and, ultimately, how is that perception and visual representation entangled in each other, in other words, to what extent is the observer - as a visually involved subject - inseparable from the visual representation that is observed and from which she/he develops a meaningful cognitive construction?

As Christopher Prendergast reminds us $^{3}$, etymologically and culturally, the word representation has a double meaning. On the one hand, an image is a representation of something in the sense that it is in the place of something else. From this point of view, it is a kind of substitute of what it represents: a "basic sense of representing is that of being instead of: a present term " $\mathrm{b}$ " is instead of the missing term " $a$ ". [...] Accordingly, representation is based on a principle of substitution. The substitution can take the form of a simulacrum [...]" (Prendergast, 2000, 5). If art is the creation, by visual means,

\footnotetext{
2 Jan van Eyck wrote: Johannes de eyck fuit hic, 1434. That is, the painter said Jan van Eyck was here instead of writing, like it would become normal, "Jan van Eyck dud" or "Jan van Eyck saw".

3 "The term 'representation' has a complex semantic history ... But we can discriminate two basic meanings, although the discrimination is problematic by virtue of areas of overlap and confusion between the two. First, there is the sense of represent as re-present, to make present again, in two interrelated ways, spatial and temporal: spatially present (in the sense of the German darstellen, "to put before", "to put there") and present in the related temporal sense of the present moment (to present there and now). This meaning has an ancient lineage, deriving in part from the Latin repraesentare as "bringing to presence again", usually understood as the literal reappearance of an absent person or object but also carrying the sense of making present again by means of a simulacrum and thus aligning the concept of representation with notions of illusion. Representation as the illusory representing of the once-present object connects with a theme that in one way or another runs back to Plato's's [sic] censuring of the imitative arts... The second basic meaning of represent is that of standing for: a present term " $b$ " stands in for an absent term " $a$ ". ... Representation in this sense thus rests on a principle of substitution. The substitution can take the form of a simulacrum, thus curling back into the definition of represent as making present, but it is not reducible to it. There can be only one kind of simulacrum, namely, the copy that produces the illusion of presence (Plato's phantasma), whereas there can be many kinds of substitution whereby one thing can stand for or indicate another [this wider sense of representation as standing for]" (Prendergast 2000, 4-5).
} 
of a material image intended to be visually perceived by someone else, that image is the image of something - be it itself or something else beyond. Most times, however, it is both: the set of pictorial marks visibly present on the surface and what these marks represent or aim to visually represent.

Thus, images are paradoxical objects as they allow, simultaneously, to see something as being and not being there (Mitchell 1986, 17), to see what is in them and beyond them, to see both surface and space - knowing that, although discrepant, both realities are inextricably linked by the construction designed by the artist. Notwithstanding, if the image is paradoxical, so is its observer: he/she is an individual who is capable of sustaining this double consciousness of the surface and space, to make compatible what is presented with what is represented; capable, therefore, of seeing the painting or photograph and this "something else" represented by it. In this sense, as stated by E.H. Gombrich (1909-2001), "we represent or describe something to someone" (Gombrich 1974, 172), meaning that all representation is always the representation of something made by someone to be seen by someone else.

On the other hand, an image is a representation of the absent:

"The sense of represent as re-present, to make present again, in two interrelated ways, spatial and temporal: spatially present (in the sense of the German darstellen, 'to put before', 'to put there') and present in the related temporal sense of the present moment (to present there and now). This meaning has an ancient lineage, deriving in part from the Latin repraesentare as 'bringing to presence again', usually understood as the literal reappearance of an absent person or object but also carrying the sense of making present again by means of a simulacrum and thus aligning the concept of representation with notions of illusion". (Prendergast 2000, 4-5)

As representation of the absent, the image means the ability of representing not only the near, the visible and the material, but also the distant, the invisible, the spiritual and even the non-existent. In this sense, representation, as understood in its dual ability to represent both objects and events, does not primarily refer to what is visible but rather to everything which can be made visible via visual creation - not in the real world but in the fictional world of representation ${ }^{4}$. In this sense, representations are apparitions.

Therefore, the representation is based on the establishment of a powerful communication between the artist and his/her observer, triggered and reinforced by the fact that the creator is, simultaneously, both author and observer, not only in the sense that any painter is an observer but, above all, because he/she is, of course, his/her first observer and for himself/herself, model of all subsequent observers (Gombrich 1974, 182; Wollheim 1987, 100). So, being an observer does not only mean being a certain kind of person but also playing a certain kind of role: someone who seeks to understand the meaning of representation and in whose mind the painter seeks to create a certain kind of experience. Image, as the representation of the absent, means, thereby, transforming the viewing experience

\footnotetext{
4 As inventions, representations are not pure transcriptions from direct observation of the world but imaginary creations that integrate information obtained by this so that what is represented remains recognizable (Arnheim 1986, 159).
} 
in a transcendent experience: a visionary experience. This visionary representation effect leads, consequently, to the transformation of the observer in a witness of exceptional events, which often take place in an extraordinary world and space. This is the case of most religious paintings and, in particular, of the extraordinary mystical visions created in the ceilings of Baroque churches. But it is also, in terms of visual and emotional impact, the case of the apparitions of the invisible in the first X-ray photographs by Wilhelm Röntgen (1845-1923), dated 1895, or the following year, in Portugal, by Augusto Bobone (1825-1910) (cf. Medeiros 2014).

The same is applied to many of the photographs by the unknown - but famous Portuguese naturalist photographer - Francisco Afonso Chaves (1857-1926), personal friend of King Carlos of Portugal (1863-1908) and, even more, of the Prince Albert of Monaco (1848-1922), with whom he shared interests, scientific projects and travelled with. Afonso Chaves kept contact with a vast number of Portuguese and European scientists - including some of the first Nobel Prize Laureates - with whom, in some cases, he not only kept contact by mail, but also became friends. He travelled tirelessly and his photographic work, built largely along his scientific travels, acquires, due to its size, distinctive qualities and characteristics, an autonomous status. Entangled in science - even by its almost exclusively stereoscopic nature - it affirms itself as one of the most remarkable creations in the history of Portuguese photography (cf. Reis 2010a, 2010b Reis, Reis 2011 Reis 2012 Reis 2013 Reis 2014 Reis 2015).

In 1903, in one of several trips to London, Francisco Afonso Chaves shows us a bustling city from the point of view of a traveller on the first floor of a modern tramway [Fig. 3]. When placed in a 3D display prepared for the stereoscopic photographs took by a Vérascope camera - a system to which he remained loyal to - the result is the automatic construction by the observer of a truthful spatial perception and impressively three-dimensional. In this case, the young man in the foreground, together with his colleagues, takes the place and the point of view of the young Lebanese, providing us a direct view instead of its reflection, as in the photo by Spencer Platt. Also unlike the latter, the photographer travels in his own vehicle and emerges as a visually involved subject thus contributing to strengthen our involvement in the visual experience of others.

Francisco Afonso Chaves places us inside the vehicle and, in this manner, compels us into a reinforced participation in the visual experience up to the point of confusing it, largely because of the stereoscopic effect, with the very own sensation (cognitive but also physical) of presence: we are there, in 1903, in that busy street of the world's biggest empire capital and the most cosmopolitan European city, which over the following years would go through two wars, bombings and destruction. The tramway, we discovered, goes through the London Bridge towards the heart of the City and the only evidence that it survived this history of ruins and reconstruction is Fishmonger's Hall - the building topped by a pediment, on the other side of the bridge, on the left.

The primacy of vision comes to light in another photograph, dated $5^{\text {th }}$ September 1904 [Fig. 4], in which an individual who keeps the box of an optical device (almost certainly a camera), is lying on top of the Vista do Rei viewpoint facing the sea and not the lake Lagoa das Sete Cidades (Azores) - the privileged view from this viewpoint - he observes something that we are not allowed to see 
and, most likely, he photographs that vision ${ }^{5}$. In this case, Afonso Chaves is the photographer's photographer - the one who records someone caught in the act of seeing and visually representing something.

Such representations will go through a development process - a fundamental step in creating the photographic image and, in some cases, in the discovery of something which for the subject was not visible or that, until then, had no existence in his/her visible world. At this point, the photographer is the one who creates a revelation out of darkness and, in the process, will transform the very visual subject in a different subject and the visual experience in a visionary experience. Accordingly, such a transcendent enlargement of the image and visual experience can be qualified as an apparition, in result of which the privileged sense of presence is not only reinforced, but also acquires new, perceptive, and emotional dimensions.

\section{Vision / Clairvoyance}

In 1920, only two years after the end of the Great War, whose destruction in the fields and in the cities he could still observe and register, Francisco Afonso Chaves (1857-1926) was once again in France. In Laon, in the region of Picardy, relatively close to the border with Belgium, he visited a friend on the $12^{\text {th }}$ June and, in the privacy of his office, he photographed him in three successive images which together form a picture over three consecutive time points [Fig. 5]. However, besides a peculiar portrait, the three images form a series, an example among many in the photographic work of Afonso Chaves, which thus demonstrates his disbelief in the completeness, autonomy and selfsufficiency of a single photographic image. Notwithstanding, at the same time, this small series is also the representation - made of registration and visual fiction - of the dynamic relationship of a body with space.

In the first image, we see the motionless body, truthfully three-dimensional and perceptually recognisable, of his friend Berthraut ${ }^{6}$ at his desk; in the second, with the previous framework, we perceive (more than what we see) the moving body becoming a dynamic track, luminous, intangible and indeterminate; in the third and final one, in the numerical order included, most likely, by the author himself in the sheets of glass, the office is uninhabited, the chair is separated and a slight change in the framework, by rotating the camera horizontally, allows to deduce, through the opened door on the left side of the image camera that the body which was previously present departed from

\footnotetext{
5 As far as we know, assuming from the set of images to which this seems to belong, the individual would integrate the group that accompanied Prince Albert of Monaco during his visit to São Miguel island and which Francisco Afonso Chaves led in a trip to this site particularly dedicated to the exercise of viewing pleasures.

6 Contrary to the description made in Museu Carlos Machado's inventory and stated by myself previously (Reis 2011), the name should be Berthaut instead of Berthant, in reference to Léon Berthault (1864-1946), a French poet, author and novelist, born in Le Havre, who was Professor of English Literature and Member of the Superior Council of Maritime Navigation and Fishery as well. The more precise information given by Afonso Chaves is handwritten in the interval of the stereoscopic pairs CAC3510 ("Em Laon - Berthaut - 12/6/920") and CAC3513 ("Em Laon Casa Berth - 12/6/920").
} 

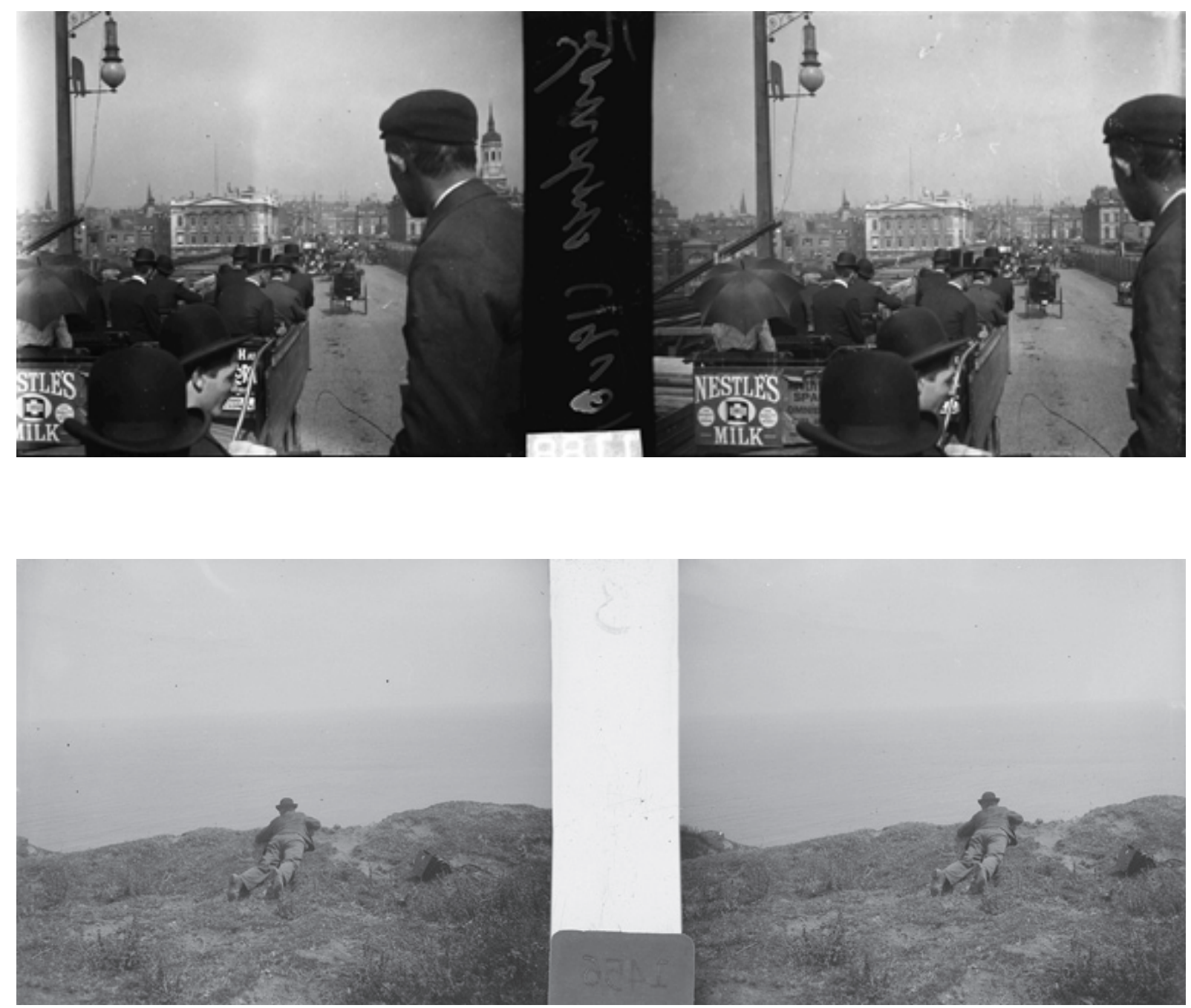

[Fig. 3]

FRANCISCO AFONSO CHAVES (1857-1926) London 1903

View of a traveller on the first floor of a modern tramway
[Fig. 4]

FRANCISCO AFONSO CHAVES (1857-1926)

Azores 5th September 1904

Lagoa das Sete Cidades 
the visible space.

This series in particular, for its temporal and narrative coherence, has an undeniable cinematic quality: it presents us three successive moments of the relationship of a body with space ${ }^{7}$. But more importantly, it has a quality that might be designated as clairvoyant: by presenting three moments of transformation of our visual perception, from the perception of the visible to the mere memory of it, it provides us, in the course of this process, the ability to see what we would never be able to see without the picture: the metamorphosis of the visible into invisible, of the material into the immaterial, of the seemingly solid into pure light. In this regard, Francisco Afonso Chaves transforms the visual subject into a seer subject: the one who sees beyond the visible and, in that act, is able to see what otherwise would be invisible.

The perspectival and fictionally modern idea, born in the Renaissance, of the observer as the one who sees through (i.e., the surface of representation) and the consequent idea of the surface like an open window, according to L.B. Alberti (1404-1472), or through transparent glass, according to Leonardo da Vinci (1452-1519), is in Francisco Afonso Chaves doubly explored: his representations are actually in glass (both negative and positive) and it is through it, with a stereoscopic device, that the viewer is led to see another world which, being fictional, is perceptually truthfully and sensory convincing. Thus, the seer subject is not just the one who is endowed with the ability to see but that who is endowed with the ability to see more (even if it is necessary to find in a machine the necessary extension of visual faculties of his/her body). Seeing more means both seeing what is present in the visual world and that is usually invisible, but also seeing what is invisible because it is simply absent from the visible world.

In that sense, image as a representation, seen in the double sense of being in place of and of representing the missing, does not mainly refer in essence to what is visible but rather to everything which, by means of representation, can be made visible, i.e. "to be seen face to face" (Wollheim $1987,64)$ - not in the real world but in the fictional world of representation. As inventions or fictions, visual representations, especially photographic ones, are not pure transcriptions of the world but imaginary creations that integrate the information obtained through its observation and register so that what is represented remains recognisable (Arnheim 1986,159). Nor do they refer to something which is necessarily visible in our immediate world but relate to the content and the widest meaning of the concept of the world, understood as everything which has existence in the cognitive sphere of the subject or that constitutes a collectively shared experience. Therefore, representation, in its complex relationship with reality, fiction and illusion, is centred both in the invisible world as well as in the visible, trying to show what cannot be seen, to make concrete or representable what is unrepresentable and, ultimately, what is spiritual (cf. Kubovy 1986).

\footnotetext{
7 Being debtor of the pioneering experiments of Eadweard J. Muybridge (1830-1904) and Étienne-Jules Marey (1830-1904), inseparable from the new art of cinema and establishing curious relationships with the futurist work of Anton Giulio Bragaglia (1890-1960), this series has, however, a very unique nature. Besides being the portrait of someone and the representation of a body's dynamic relationship with the space where it is, it is also a narrative fiction about space itself and how it transforms visually, but even more, subjectively before our own eyes as it is inhabited, crossed by and uninhabited by that body.
} 


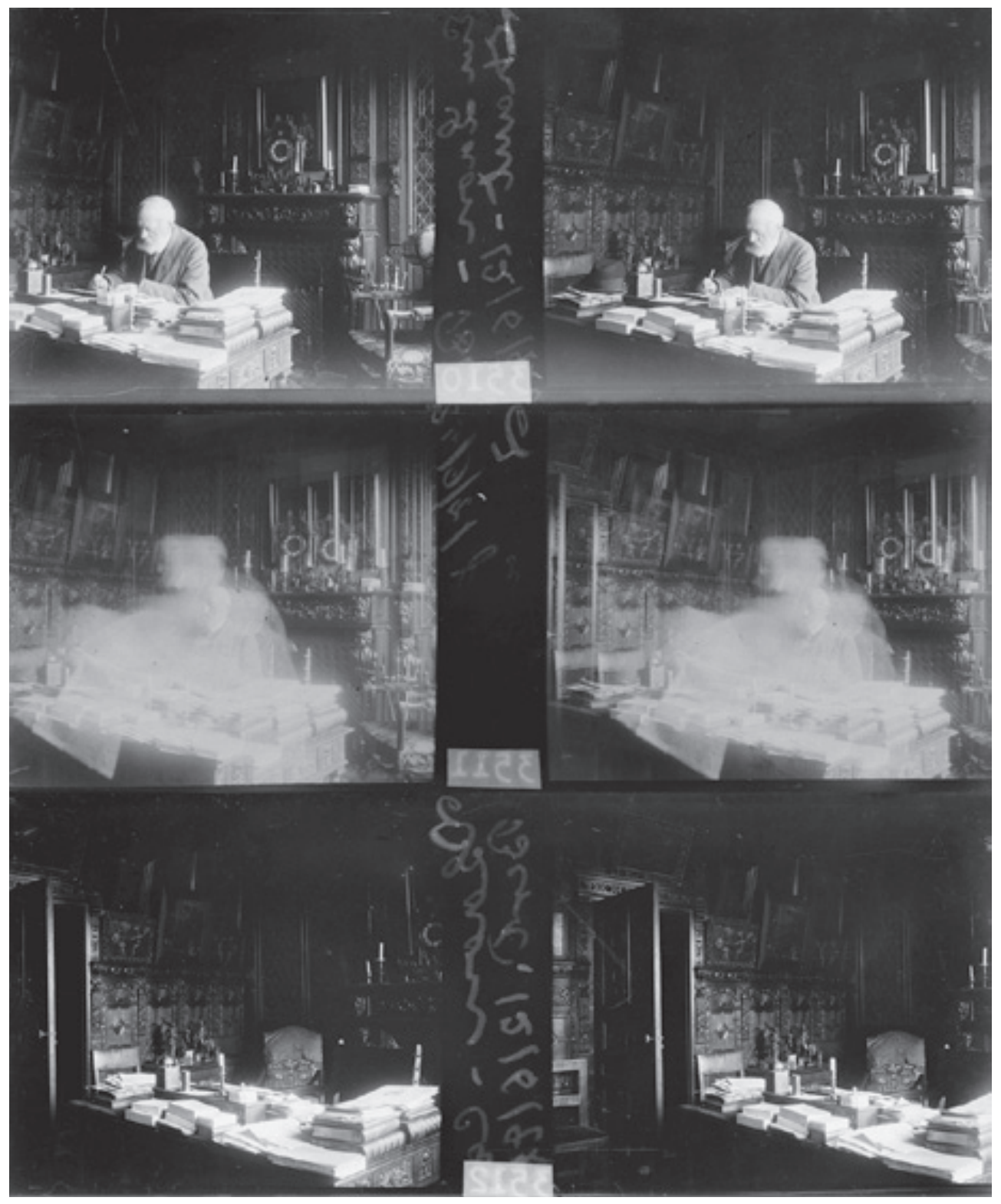

[Fig. 5]

$\overline{\text { FRANCISCO AFONSO CHAVES (1857-1926) }}$

France 1920

Picture of three consecutive time points 
Image as a representation of the invisible or of the absent means, thereby, the transformation of the observing experience into a transcendent experience: into that visionary experience. Consequently, this visionary effect of representation leads to the transformation of the observer into a witness of exceptional events often occurring in an extraordinary world and space: into a visionary witness. However, in the work of Afonso Chaves, due to its stereoscopic nature and to the fact that the observation is mediated by a building artefact of a viable spatiality (almost tactile or para-tactile), the image is not only a window but a credible three-dimensional world and the subject is someone visually and emotionally immersed in his/her own vision, in the world of fiction or, if we wish, the visionary experience. That seer subject.

This clairvoyant quality which corresponds to a visualenlargement of the visualby thetranscendence of the visible is, thus, inseparable from a reflection and re-evaluation of the concept and of the role of the observer, recurring themes in the vast and original work of Afonso Chaves. This is what occurs in a wide range of photographs in his collection which, through overlapping or merging, in the same support of distinct spatial and temporal records (i.e., of the fixing of different images in the same glass), the unit, materiality and opacity of the bodies gives rise to its transparency, multiplicity and immateriality. Thus, seeing through the surface becomes seeing more and seeing differently: seeing through bodies.

In this dematerialisation of bodies, Afonso Chaves creates images of great beauty which are, at the same time, deeply subversive from the usual concepts of the photographic image as a truthful record of the real or of an instantaneous and miniaturised automatic copy of the world. In these photographs, the unstable boundary between familiarity and strangeness is driven to the point of causing a deliberate disintegration of boundaries between the visible and the invisible, subverting the photography quality as a privileged means of recording the first and, simultaneously, asserting its oneiric and fictional dimension - all its power of a paradoxical image. The strange beauty of the achieved results is particularly evident in some of the stereoscopic merges carried out at the end of his life - such as the composite photograph made on the Vasco da Gama ship or the works reached by merging photographs from different locations made on different days: The Manueline cistern of Mazagan (current El Jadida) and the city of Rabat - a series held on the second and last trip of the author to Morocco. The light, coming in from the cistern domes through the oculus openings, bursts in the form of unexplained flashes in the skies, waters and streets of Rabat, approximately two hundred kilometres North. Or, as singular appearances - exactly as in the case of the group of friends, among which is Francisco Afonso Chaves himself, whom we see being transported from the sidewalk of the Lagoa das Sete Cidades to an unidentified wood in the same island [Fig. 9].

\section{Image / Reflection}

In Rome, on his third trip to this city, Francisco Afonso Chaves, on the $5^{\text {th }}$ April 1913 , made a series of photographs from the inside of a museum. In one of them, we see in the centre of the room and in the foreground, the glasses of a large showcase. In its mirror image we see the other side of the space and, particularly, the window at the opposite wall of the room: on this side, behind the camera, the 
photographer and us - just like the mirrored glasses of the Ray-Bans in Spencer Platt's photograph. Another photograph of that series, with the same view of this museum room, appears overlapped with another belonging to a different series, dated the same date (from which three photographs remain) and where, on a street in Rome, soldiers are seen around an iron cylinder from which a second one is taken [Fig. 10]. Thus, in addition to the mirror images of the museum room's in the glass showcase there are also the spectra of the soldiers and of the dirty road recognisable by the cobblestone sidewalks. After all, what initially appears to be plain reflexes on glass is a paradoxical merge in the same image of both interior and exterior: through it, the large window disappears, the soldiers look like figures that inhabit the large showcase of the museum and the cobbled roads trigger a strange dilution of the solidity of the room's floor ${ }^{\text {. }}$

In these photographs, the viewer has a more demanding role - active and participatory, not merely passive - and occupies a privileged point of view, which no longer corresponds to a single place but, rather, to several different places spatially and temporally merged. Geographically undefinable and in conflict with the laws of classical physics, but also with the laws of human vision biology, as a fiction, this point of view corresponds mainly to an abandonment of the subject of the real world - and, in this sense, it reflects its release from the visible empire and thus allows to see more through the image. The fact that, in this case, fiction takes place inside a museum, a modern sacred space - one which allows the modern visual, emotional and spiritual experience of clairvoyance - makes the photographic work of Francisco Afonso Chaves even more interesting.

That is to say, in the perception of certain representations the active participation of the observer leads him/her not only to a visual experience but also to a visionary experience, an extraordinary and supernatural vision, in which he/she is a participant and simultaneously a witness. Through the subject (believer), he/she voluntarily and consciously participates or feels to be involved in that ultimate mystery: the image making visible the invisible or revealing this in that.

The viewer's active participation is a fundamental aspect of this visualisation of the invisible and, in this sense, of the construction of the visual. In other words, the construction of fiction requires the voluntary participation of the subject, his/her collaboration - what Gombrich (1960) calls the beholder's share. To this end, the artist seeks not only to generally capture his/her attention and interest but, above all, to stimulate their subjective and cognitive mechanisms responsible for the construction of perceptions from insufficient, ambiguous or even contradictory information. Mechanisms such as the capability of projection, inference, expectation and recognition that artists know and in which they trust. Therefore, the active participation of the observer means an awareness of the image as a representation and of representation as an illusion. This is what happens in the relationship with the photographs of Spencer Platt and Afonso Chaves.

This active and voluntary participation of the subject in the process of illusion is based on what Michael Kubovy defined as collusion between the artist and the observer (cf. Kubovy 1986, 77-82): if the former meets and seeks to take advantage of the perceptive mechanisms that lead the observer

8 These are the photographs with the inventory numbers CAC2909, CAC2910 e CAC2911. 

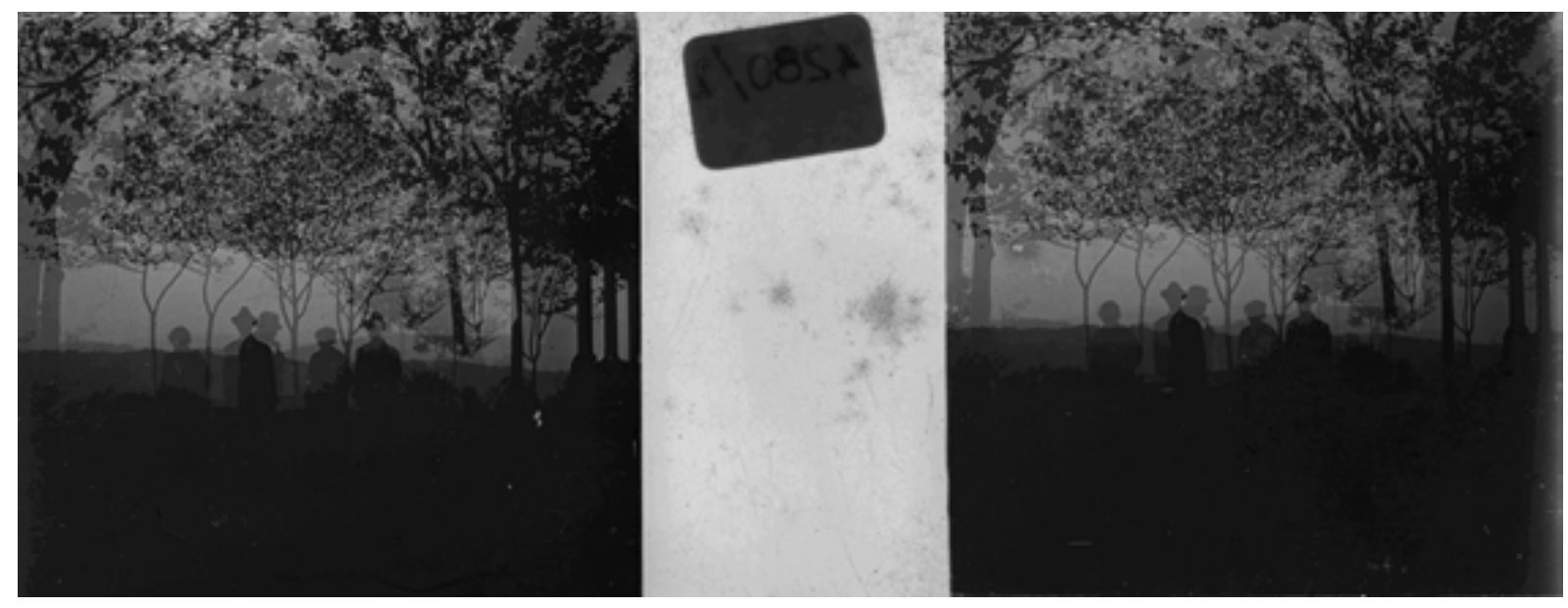

[Fig. 9]

FRANCISCO AFONSO CHAVES (1857-1926)

Azores

Unidentified wood in Azores 

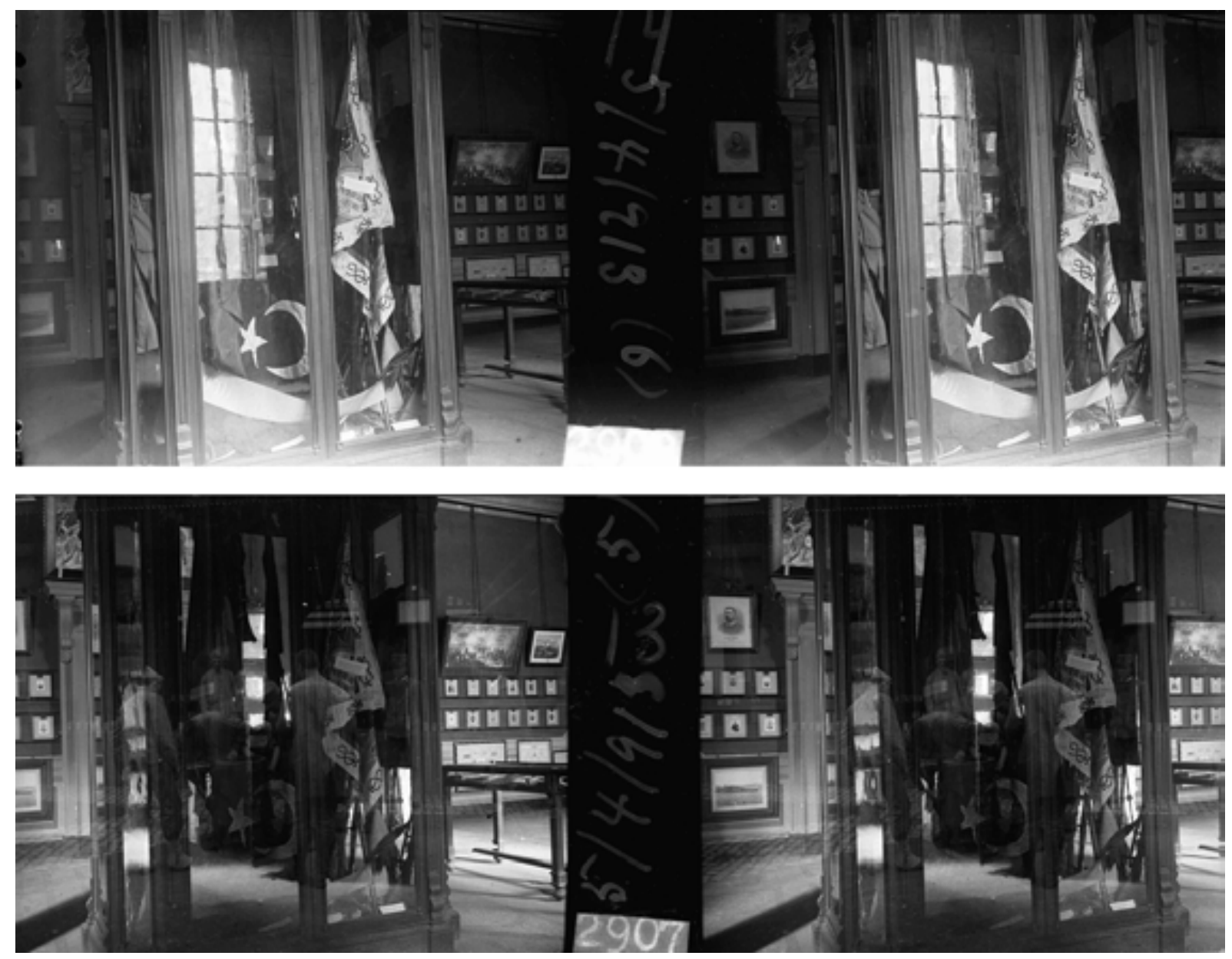

[Fig. 10]

$\overline{\text { FRANCISCO AFONSO CHAVES (1857-1926) }}$

Rome 5th April 1913

Inside of a museum 
to an illusion, the former is aware that what he/she sees is an illusion and his/her mind actively participates in the process leading to it. By implying awareness and participation, illusion differs from hallucination: if this is the unawareness of the perceptual mistake, the first is a conscious perceptual mistake and, in that sense, a mental collusion between two subjects mediated by an image. Therefore, the awareness of illusion implies an awareness of the contradictions and of the ambiguities - i.e., of the paradoxes - inherent to the dual nature of the representation and its perception. Indeed, it is the inability or incapacity of our perceptual system to reconcile these paradoxes, contradictions and ambiguities, which "originates the experience of illusion" (Kubovy 1986 84) or visual fiction.

This fiction invades the phenomenological space of the observer and tries to merge with it, seeking to enlarge the real space but snatching the subject from it - a consented and desired kidnap of the observer (Reis 2006). Thus, the image as illusion or fiction depends on a joint effort, on a double will and, ultimately, on a consent from the subject. It depends, after all, "on that momentary and willing suspension of disbelief, which constitutes the poetic faith" (Coleridge 1815 to 1817, 314). 


\section{Bibliography}

Arnheim, Rudolf. 1986. "Inverted Perspective and the Axiom of Realism". In New Essays on the Psychology of Art, 159-185. Berkeley e Los Angeles: University of California Press.

Coleridge, Samuel Taylor. 1815-1817. Biographia Literaria; or Biographical Sketches of My Literary Life and Opinions. In Samuel Taylor Coleridge: The Major Works, org. by H. J. Jackson, 155-482. Oxford: Oxford University Press, 2000.

Gombrich, E. H., 1960. Art and Illusion: A Study in the Psychology of Pictorial Representation. (5ª ed.) Londres: Phaidon Press, 1994.

Gombrich, E. H., 1974. "Mirror and Map: Theories of Pictorial Representation". Conferência em Maio 1974 na Royal Society. In The Image and the Eye: Further Studies in the Psychology of Pictorial Representation, E. H. Gombrich, 172-214. Oxford: Phaidon Press, 1982.

Kubovy, Michael. 1986. The Psychology of Perspective and Renaissance Art. Cambridge: Cambridge University Press.

Medeiros, Margarida, ed. 2014. Augusto Bobone: Foto-Radiografias. Lisboa: Documenta.

Mitchell, W. J. T., 1986. Iconology: Image, Text, Ideology. Chicago: Chicago University Press.

Prendergast, Christopher. 2000. The Triangle of Representation. Nova York: Columbia University Press.

Reis, Vitor dos. 2006. O Rapto do Observador: Invenção, Representação e Percepção do Espaço Celestial na Pintura de Tectos em Portugal no Século XVIII. (PhD. thesis in Fine Arts/ Theory of Image presented to Lisbon University). Lisboa: S.n..

Reis, Vítor dos. 2010a. A República e a Modernidade: Revelar, Renovar, Regressar. Ponta Delgada: Presidência do Governo dos Açores / Direcção Regional da Cultura / Museu Carlos Machado.

Reis, Vitor dos. 2010b. "O Fotógrafo Estereoscópico: a Descoberta da Obra Fotográfica de Francisco Afonso Chaves (18571926)". Estúdio I, 2: 50-56.

Reis, Vitor dos. 2011. "O Rasto de um Corpo no Espaço, ou o Observador como Sujeito Vidente em Francisco Afonso Chaves (1857-1926)" :Estúdio II, 4: 12-18.

Reis, Vitor dos. 2012. "Francisco Afonso Chaves, o Fotógrafo Errante". Açoriano Oriental. CLXXVIII, 18000, 19 Agosto $2012:$ 18.

Reis, Vitor dos. 2013. "Fumo, Vapor e Lava: as Paisagens Incertas de Francisco Afonso Chaves (1857-1926)". Estúdio IV, 8: 42-51.

Reis, Vitor dos. 2014. "A Ascensão das Máquinas Voadores: Francisco Afonso Chaves e Jacques Henri Lartigue no Campeonato Gordon Benett em Paris (1906)". Actas do Colóquio Movimento e Mobilização Técnica (coord. José Bragança de Miranda). Lisboa: CECL/FCSH-UNL (no prelo).

Reis, Vítor dos. 2015. "O corpo como hipótese: sucessão, sobreposição e transparência em Francisco Afonso Chaves (1857-1926)" (in press).

Wollheim, Richard. 1987. "What the Spectator Sees". In Painting as an Art, 43-100. Londres: Thames and Hudson. 